\title{
Improving the survival and growth of African catfish (Clarias gariepinus) fingerlings by using Nile tilapia
}

\section{Ebtehag Abdel Razek Kamel}

Department of Genetics and Breeding, Central Laboratory for Aquaculture Research, Abbassa - Abo-Hammad, Sharkia

E-mail: ebtehagkamel@yahoo.com

\begin{abstract}
In an attempt to improve the survival rate of African catfish, Clarias gariepinus fingerlings, an experiment was conducted in six cement ponds (15 $\mathrm{m}^{3}$ per each). African catfish were cultured with Nile tilapia, Oreochromis niloticus as species combination at three different ratios with two replicates. Each pond was stocked by 40 O. niloticus $(7.8 \pm 1.3 \mathrm{~g})$, meanwhile 40,30 and 20 C. gariepinus $(8.9 \pm 1.7 \mathrm{~g})$ were stocked at group 1,2 and 3 for 10 weeks. Fish were fed for satiation on $30 \%$-protein diet twice daily; five days a week for 10 weeks. At the end of the experiment, ponds were drained and fish were harvested, counted, and weighed. The catfish were classified by weight to four classes; class 1 (20-25 g), class 2 (25-30 g), class 3 (30-40 g), and class 4 (40-50 g). Growth performances of both fishes were significantly differenced among the different groups. The best growth for $C$. gariepinus and $O$. niloticus was recorded in groups 2 and 1, respectively. No significant difference in $C$. gariepinus length was recorded, while $O$. niloticus length was significantly differed $(\mathrm{P}>0.05)$ between treatment 1 and other treatments. C. gariepinus classes were significantly differed among the different fish groups. Among the different groups no significant differences in catfish survival (80-85\%), while it was significantly differed in tilapia (89.9-98.3\%). The results of the present study showed that using $O$. niloticus fingerlings has a positive impact on $C$. gariepinus growth and survival rate and it could be recommended using $O$. niloticus in $C$. gariepinus culture as a technique to minimize their cannibalism. Minimizing the use of grading and sorting of catfish which lead to avoid the stress resulting from their use on African catfish Clarias gariepinus and reduce the production costs
\end{abstract}

Key words: African catfish, Clarias gariepinus, Nile tilapia, growth, survival.

\section{Introduction}

African catfish, Clarias gariepinus $C$. gariepinus is distributed in Africa and Asia (Teugels and Adriaens, 2003). Nowadays, African catfish has more contribution in aquaculture production systems world-wide because of their fast growth rate, high disease resistance, aerial respiration, high feed conversion (ElNaggar et al., 2006; Ibrahim and ElNaggar 2010; Solomon and Boro, 2010). The economic study of catfish production in Egyptian fisheries was recorded by Abdel-Hafez and El-Caryony (2009). A review in the status of African catfish (Clarias gariepinus) aquaculture around 
the world was reported by Gomaah and El Nagar (2004).

There are many studies on using $C$. gariepinus to control and reduce the overpopulation of Nile tilapia (El Gamal et al., 1998; Abdel-Tawwab, 2005; El Naggar, 2007; Ibrahim and El Naggar, 2010; Abdel-Hakim and Amar, 2010). The above mentioned studies had assessed the efficiency of $C$. gariepinus in controlling unwanted Nile tilapia, $O$. niloticus recruits in grow out and to evaluate the performance of $O$. niloticus in polyculture system with catfish under low-input production system.

One of the problems restricts the $C$. gariepinus farming is cannibalism (large fish eat small one) among. Hecht and Pienaar (1993) focused on the two principal causes of sibling cannibalism which may be genetic and/or behavioral; the latter being influenced directly by environmental factors. To reduce cannibalism of $C$. gariepinus in hatcheries and fish farms it should be grading and sorting by size. It is expected that grading minimizes the stress imposed by the larger individuals over small ones resulting in improved fish growth and production (Seppa et al., 1999).

African catfish exhibits a strong differential growth rate leading the farmers to grade their fish once or twice during the production cycle (Verreth and Eding, 1993). Within fish farming grading, i.e. the process of sorting to approximate size, changes the group composition from heterogeneous to homogeneous (Martins et al., 2005). On the other hand, grading and sorting processes are overcost and could cause a handling stress on fish, which may reduce their growth. Abdel-Tawwab et al. (2006) stated that fish cannibalism was affected by stocking density, feed quality and availability, and the presence of shelters such as submerged macrophytes. This hypnotized that the availability of food for $C$. gariepinus via their culture with $O$. niloticus may reduce their cannibalism resulting in enhanced growth and survival. Therefore, the objective of the present study is using $O$. niloticus to improve C. gariepinus growth and survival rate.

\section{Materials and methods}

The study was carried out in 6 cement ponds (15 $\mathrm{m}^{2}$ per each), Central Laboratory for Aquaculture Research (CLAR), Abbassa, Abou Hammad, Sharkia. For all ponds inlet and outlet of each pond was screened using fine mesh screen to prevent entrance of undesirable fish. The water source was from Ismalia canal as a branch from Nile River. Nile tilapia, Oreochromis niloticus and African catfish, $C$. gariepinus were obtained from Egyptian Center for Applied Aquaculture, Kafer El Sheikh, Egypt. Fish were transformed in plastic tanks provided with aeration to CLAR lab and acclimatized for two weeks in the indoor wet lab, Department of Fish Genetics and Breeding, CLAR. After that the fish were distributed in complete randomized design to six ponds divided to three groups; two replicates for each. Each pond was stocked by 40 O. niloticus $(7.8$ $\pm 1.3 \mathrm{~g}$ ), meanwhile 40,30 and $20 C$. gariepinus $(8.9 \pm 1.7 \mathrm{~g})$ were stocked at group 1, 2 and 3 for 10 weeks. Fish were fed for satiation on $30 \%$-protein diet twice daily; five days a week for 10 weeks. Water samples from each pond were collected every two weeks throughout the experiment. Water temperature was $27{ }^{\circ} \mathrm{C}$ \pm 2 , dissolved oxygen range between 3 $5 \mathrm{mg} / \mathrm{L}, \mathrm{pH}$ range between 7.2 - 8.3, nitrite range between $0.0-0.05 \mathrm{mg} / \mathrm{L}$, and unionized ammonia range between 0.09 - 
$0.2 \mathrm{mg} / \mathrm{L}$. These parameters are within the suitable ranges for fish farming (Boyd, 1990).

At the end of the experiment, ponds were drained and fish were harvested, counted, and weighed. The catfish were classified by weight to four classes; class 1 (20-25 g), class 2 (25-30 g), class 3 (30$40 \mathrm{~g})$, and class 4 (40-50 g).

\section{Results}

The final weights of $O$. niloticus and C. gariepinus were significantly differed ( $\mathrm{P}>0.05)$ among the different groups (Figure 1).

Moreover, $O$. niloticus length was significantly differed $(\mathrm{P}>0.05)$ between treatment 1 and other treatments, while no significant difference was recorded for $C$. gariepinus length (Figure 2)

There was significant difference in the percentage of fish classes among the different fish groups (Table 1). The highest percentage was recorded for class $1(54.4 \%)$ in group 1 , whereas the lowest one was obtained at group $3(24.2 \%)$.

For class 2, no significant difference was recorded for fish groups 1and 2 (14.7 and $14.6 \%$, respectively), while it was significant for fish group 3 (36.4\%). However group 2 produced the highest percentage $(35.4 \%)$ for class 3 .

On the other hand, the lowest percentage for class 4 was recorded in fish group $1(7.4 \%)$ and the highest one was obtained in fish group 2 (15.2\%).

O. niloticus survival rate was significantly differed $(\mathrm{P}>0.05)$ among all fish groups (Figure 3), meanwhile no significant difference was observed for $C$. gariepinus survival rate.

\section{Discussion}

The present study has indicated that using $O$. niloticus at different ratio with C. gariepinus effected the growth of both fishes. The presence of $O$. niloticus in the ponds with $C$. gariepinus acted as a barrier, reduced the cannibalism, the aggressive behavior, and minimized the gap $C$. gariepinus size. From the results of this study, using 40 O. niloticus with $30 \mathrm{C}$. gariepinus gave the best growth followed by $40 \mathrm{O}$. niloticus with $20 \mathrm{C}$. gariepinus. These results were in full agreement with Abdel-Hakim and Ammar (2010) who reported that 1 C. gariepinus: 20 O. niloticus gave the optimum growth performance and net return.

In contrast, Offem et al.( 2009) recorded that the final mean weight, average net and gross yields of $O$. niloticus indicated higher values for $O$. niloticus when polyculture with large and small $H$. longifilis. Van de Nieuwegiessen et al. (2009) stated that growth range of 102.1-288.6 g, both univariate and multivariate analyses indicated a significant effect of stocking density where at increasing density they observed an increase in African catfish activity. Almazán Rueda (2004) pointed out that juvenile $C$. gariepinus showed a positive effect of increasing density, reflected by increased growth performance.

The $C$. gariepinus survival was high among the different fish groups, because the $O$. niloticus presence had a positive effect in increasing the survival rate. The present results was in line with those given by Marimuthu et al. (2010), who reported that twice/day feeding regimen is the best to obtain the highest growth rate in the African catfish fingerlings. Otherwise, Abdel-Tawwab (2005) reported that the predation rate of $C$. 
gariepinus increased with increasing predator size and $O$. niloticus stocking. Nonetheless, De Graaf et al. (1996) had mentioned to low $O$. niloticus survival when reared in combination with $C$. gariepinus at a low and high feeding level. Solomon and Boro (2010), stated that low survival rate for catfish Heteroclarias/ Nile tilapia at different stocking ratios $(1: 1,1: 2$, and 1:4) survival decreases as stocking density increases.

\section{Recommendation}

The present study recommended using O. niloticus in combination with $C$. gariepinus with appropriate ratio to minimize $C$. gariepinus cannibalism resulting in an enhanced $C$. gariepinus growth and survival.

\section{REFERENCES}

Abdel-Hakim, N.F. and Ammar, A. A. (2010): Effect of catfish (Clarias gariepinus) stocking densities as predator on pond productivity of Nile tilapia (Oreochromis niloticus) reared in earthen pond. Abbassa International Journal of Aquaculture, Special Issue 2010. The third scientific Conference, Al Azhar University, Cairo $17-18$ October 2010.

Abdel-Hafez, S.A. and El-Caryony, A.I. (2009): An economic study on the production of Catfish in the Egyptian fisheries. Journal of Arabian Aquaculture Society, 4(1): 19-34.

Abdel-Tawwab, M. (2005): Predation efficiency of Nile Catfish, Clarias gariepinus (Burchell, 1822) on fry Nile Tilapia, Oreochromis niloticus (Linnaeus, 1758): Effect of prey density, predator size, feed supplementation and submerged vegetation. Turkish Journal of
Fisheries and Aquatic Sciences, 5: 6974.

Abdel-Tawwab, M.; El-Marakby, H.I. and Ahmad, M.H. (2006): Anticannibalism in Nile tilapia, Oreochromis niloticus (L.): effect of stocking density, feed quality and submerged macrophytes. Indian Journal of Fisheries, 53: 124-131.

Almazán Rueda, P. (2004): Towards Assessment of Welfare in African catfish, Clarias gariepinus: the first step, Fish Culture \& Fisheries Group, Wageningen Institute for Animal Sciences. Wageningen University, The Netherlands, p. 152.

Boyd, C. E. (1990): Water quality management for aquaculture. Alabama Agriculture Experiment Station Auburn University, Alabama. P482.

De Graaf, G. J.; Galemoni, F. and Banzoussi, B. (1996): Recruitment control of Nile tilapia, Oreochromis niloticus, by the African catfish, Clarias gariepinus ( Burchell 1822) and the African snakehead, Ophiocephalus obscuris. I. A biological analysis. Aquaculture, 146: 85-100.

El Gamel, A. A; Abdel-Halim, A. M.; Abdel-Razek, E. and Solomon, A. (1998): Biological studies on the Nile perch Lates niloticus (L) and African catfish Clarias gariepinus (T.) in reference to their food habits and predation pattern in culture ponds. Egyptian Journal of Agriculture Research, 76: 335-349.

El-Naggar, G.O • (2007): Efficiency of African Catfish Clarias gariepinus in controlling unwanted reproduction of Nile Tilapia Oreochromis niloticus in low input production system. Egyptian 
Journal of Aquatic Biology \& Fishers, 11(3): 105-113.

El-Naggar, G.O.; John, G.; Rezk, M.A.; Elwan, W. and Yehia, M. (2006): Effect of varying density and water level on spawning response of African catfish, Clarias gariepinus: implication for seed production. Aquaculture, 261: 904-907.

Gomaah, S.A. and El Naggar, G.O. (2004): Status of African catfish (Clarias gariepinus) aquaculture around the world: A review. Proc. The $1^{\text {st }}$ Intern.Conf.Vet.Res.Div., National Research Center(NRC), Cairo, Egypt, February $15-17^{\text {th }} \cdot$ pp. $375-383$.

Hecht, T. and Pienaar, A. G. (1993): A Review of Cannibalism and its Implications in Fish Larviculture. Journal of the World Aquaculture Society, 24: 246-261.

Ibrahim, N. and El Naggar, G. (2010): Water quality, fish production and economics of Nile tilapia, Oreochromis niloticus, and African Catfish, Clarias gariepinus, monoculture and polycultures. Journal of the World Aquaculture Society, 41(4): $574-582$.

Marimuthu, K. ; Ang, C. C. ; Muralikrishnan, S. and Kumar, D. (2010): Effect of Different Feeding Frequency on the Growth and Survival of African Catfish (Clarias Gariepinus) Fingerlings: Advances in Environmental Biology, 4: 187-193.

Martins, C. I .M.; Schrama, J.W and Verreth, J.A.J. (2005): Inherent variation in growth efficiency of African catfish, Clarias gariepinus
(Burchell, 1822), juveniles. Aquaculture Research, 9: 868-875.

Offem, B.O.; Ikpi, G. U. and Ayotunde, E. O. (2009): Effect of stocking size of the predatory African catfish (Heterobranchus longifilis V.) on the growth performance of Nile tilapia (Oreochromis niloticus L.) in pond culture. International Journal of Fisheries and Aquaculture, 1 (3): 038043.

Teugels, G.G. and Adriaens, D. (2003): Taxonomy and phylogeny of Clariidae: An overview. In: G Arratia, BG Kapoor, M Chardon, R Diogo (Eds.), Catfishes. Science publishers, Inc., Enfield (USA). 1: 465-487.

Solomon, J.R and Boro, S.G. (2010): Survival Rate in polyculture of Catfish Heteroclarias /Tilapia (Oreochromis Niloticus), Fed 2\% Body Weight. New York Science, 3(9): 68-78.

Seppa, T.G.; Peuhkuri, N.; Hirvonen, H.; Laurila, A.; Piironen, J. and Ranta, E. (1999): Narrow size regime among individuals favors rapid growth in Arctic char (Salvelinus alpinus) juveniles. Canadian Journal of Fisheries Aquatic Science, 56: 18911897.

Verreth, A.J. and Eding, E.H. (1993): European farming industry of African catfish (Clarias gariepinus): facts and figures. Aquaculture European, 18: 613.

Van de Nieuwegiessen, P.G.; Olwo, J.; Khong, S.; Verreth, J.A.J. and Schrama, J.W. (2009): Effects of age and stocking density on the welfare of African catfish, Clarias gariepinus Burchell. Aquaculture, 288: 69-75. 


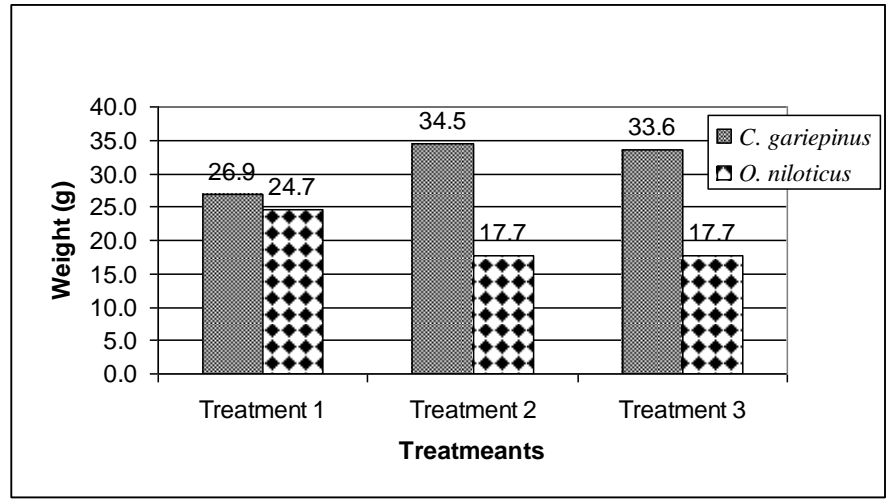

Figure (1) Growth rate of C. gariepinus and O. niloticus

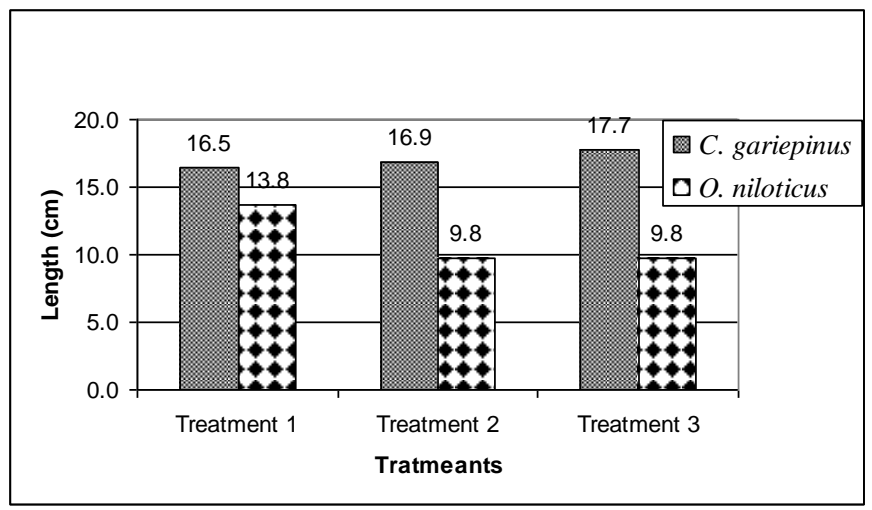

Figure (2) Length of C. gariepinus and O. niloticus

Table (1). The percentage of $C$. gariepinus classes among the different groups.

\begin{tabular}{cccc}
\hline Weight classes & Group 1 & Group 2 & Group 3 \\
\hline Classe 1 (20-25 g) & $54.4^{\mathrm{a}}$ & $39.6^{\mathrm{b}}$ & $24.2^{\mathrm{c}}$ \\
Classe 2 (25-30 g) & $14.7^{\mathrm{b}}$ & $14.6^{\mathrm{b}}$ & $36.4^{\mathrm{a}}$ \\
Classe 3 (30-40 g) & $23.5^{\mathrm{b}}$ & $35.4^{\mathrm{a}}$ & $24.2^{\mathrm{b}}$ \\
Classe 4 (40-50 g) & $7.4^{\mathrm{c}}$ & $10.4^{\mathrm{b}}$ & $15.2^{\mathrm{a}}$ \\
\hline
\end{tabular}




\title{
تحسين معلل النمو والاعاثة لإصبعيات القرموط الأفريقي باستخدام البلطى
}

\section{ابتهاج عبد الرازق كامل}

\author{
قسم التربية و الوراثة \\ المعمل المركزى لبحوث الثرونة الثروة السمكية بالعباسة أبوحماد شرقية ـ مركز البحوث الزر اعية \\ البريد الالكترونى: yahoo.com
}

\section{الملخص العربى}

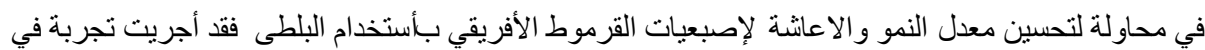

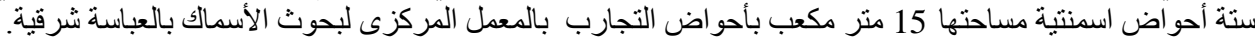

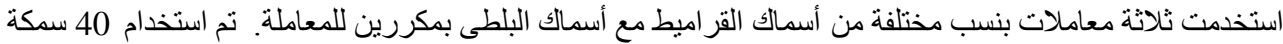

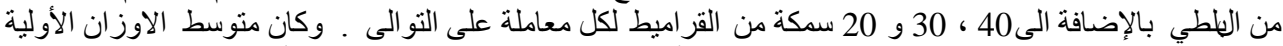

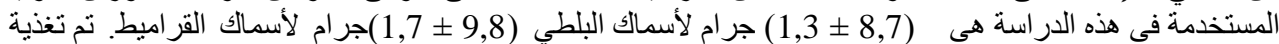

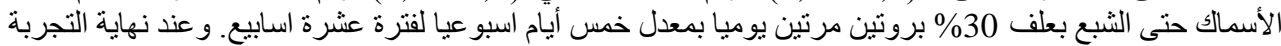

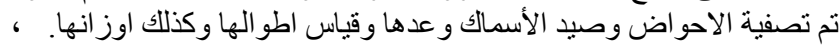
وقد أظهرت النتائج ان هنالك فروق ذات دلالة إحصائية بين المعاملات في معدلات النمو. وسجل أعلى معدل نمو في الألي

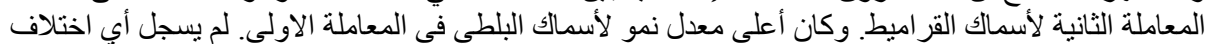

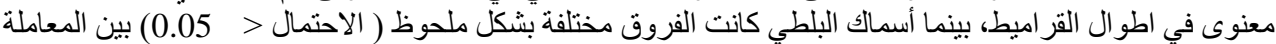
الاولى وغير ها من المعاملات.

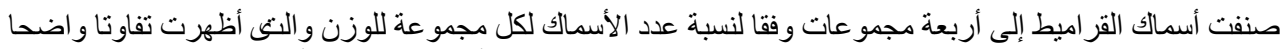

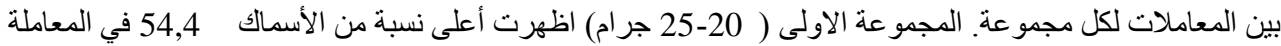

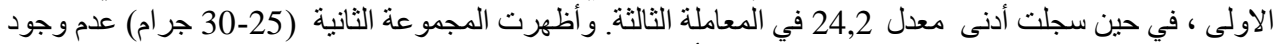

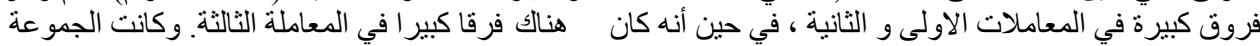

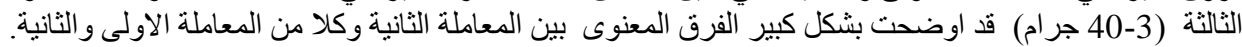

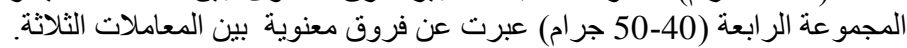

وكان معدل الاعاثة مرتفعة (80-85\%) للقر اميط ولكن عدم وجود فروق ذات ذات دلالة إحصائية بين جميع المعاملات ،

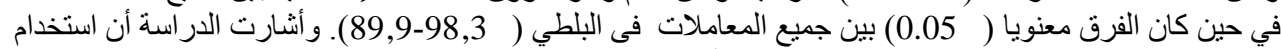

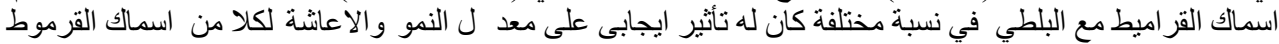
الأفريقى و البلطى.

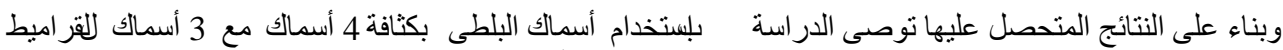

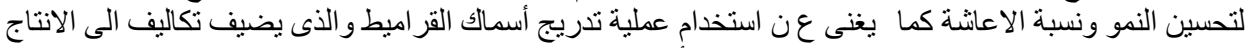

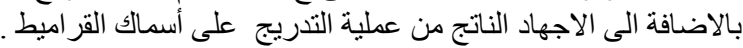

